\title{
PARALLEL IMPORTATION AND SERVICE QUALITY: AN EMPIRICAL INVESTIGATION OF COMPETITION BETWEEN DVDS AND CINEMAS IN NEW ZEALAND
}

\author{
Matthew Burgess* \& Lewis Evans**
}

\begin{abstract}
Investigations into the causes and effects of parallel importing have concentrated on price discrimination, but arbitrage can also occur on non-price dimensions. Using a natural experiment in the New Zealand film distribution industry between May 1998 and November 2001, we examine the effect of parallel importing on quality as it relates to the timing of the availability of film media. We demonstrate that a) cinema revenues were undermined as consumers substituted viewing films on parallel imported DVDs for the cinema format and $b$ ) that studios responded to the threat of parallel imported DVDs by bringing forward the release of films into New Zealand cinemas. The reduced delay between US and New Zealand cinematic release dates is shown to be consistent with the introduction of competition when timing is a dimension of quality and choice. We conclude that parallel importation of DVDs almost certainly resulted in a net increase in welfare in New Zealand.
\end{abstract}

\section{INTRODUCTION}

Parallel importing is the importation of legitimately-produced goods without the consent of the relevant copyright, trademark or patent holder (or her agent) in the recipient country. ${ }^{1}$ It is not trade in pirated or counterfeit goods. It is an arbitrage phenomenon caused by international differences in price, associated services, availability and quality of goods. Parallel importation restrictions have analogues under competition law that has a long legal history. These are vertical restrictions - that may be territorial - imposed in domestic economies by manufacturers. ${ }^{2}$ The rationale for these restrictions in both cases is to internalise externalities in distribution such as those relating to product service and advertising. The legality of such restrictions has been the subject of a considerable

\footnotetext{
* Matthew Burgess is a Senior Associate at CRA International, Oakland, USA.

** Lewis Evans is Professor of Economics at Victoria University at Wellington, New Zealand, and a Research Principal in the New Zealand Institute for the Study of Competition and Regulation.

The authors would like to thank the following people for their assistance: Graeme Guthrie, Roy Hanrahan, Bill Hood, James Mellsop, Kieran O'Connell, Chris Osbourne, Victoria Pearson, Mark Pettit, Warren Prowse and Warwick Rothnie, and participants of the International Bar Association conference (Auckland New Zealand, 2004).

1 Parallel imports are labelled "parallel" because they are often shipped back to the country from which they originated (Valletti and Szymanski 2004:2). Similarly, Rothnie (1993:1) notes the term parallel is used because unauthorised imports are imported in 'parallel' to the authorised distribution network. Chaudhry (2004) draws a distinction between parallel imports and parallel re-imports, but we do not make that distinction here.

2 See Carlton and Perloff (2005:414-433) for a brief review of the distribution externalities that may justify vertical restraints, including territorial restrictions.
} 
number of antitrust cases. ${ }^{3}$

The effect of parallel importation on price and quantity is difficult enough to measure, and the assessment of effects on quality is even more difficult. Yet quality effects are an important determinant of the social desirability of legal restrictions on parallel importation. Parallel importation, for example, may limit even eliminate price premia that are used to support after-sales service. In this paper we explain how the parallel importation of film affects the quality dimension of timing of availablility and utilise a natural experiment to estimate that consequent welfare effects. We conclude that provided that investment in film making is unaffected there is a clear increase in welfare associated with parallel importation of films.

Assessing the magnitude of parallel trade flows is difficult because data on parallel imports is not systematically collected (Maskus and Chen 2000:4). However, some estimates of parallel trade volumes are available. NERA (1999:ix) assesses the extent of parallel importing in ten sectors within the European Union and estimates parallel trade accounts for shares of sales which range up to 15 percent. Cosac $(2003: 2)$ cites a study which estimates $20 \%$ (worth $£ 1.3$ billion) of branded pharmaceuticals sold in the UK in 2002 were parallel imports. Maskus and Chen (2000:4) cite an article which claims that up to $20 \%$ of Coca-Cola products in the UK are sourced from wholesalers in other EU countries, and that this trade was caused by differences in wholesale prices. Arfwedson (2004:5-6) cites a study estimating that parallel imports of pharmaceuticals in the EU were worth $\$ 3.3$ billion in 2001 and were forecast to rise to $\$ 7.4$ billion in 2006 .

The legal mechanism giving effect to restrictions on parallel imports is territorial exhaustion of intellectual property rights. The term "exhaustion" is used because the right of the IPR holder to prevent re-sale is said to be "exhausted" when the goods are sold (Valletti and Szymanski 2004:3). The point at which exhaustion occurs can be made to depend on the location of the sale. The extent of the territory in which exhaustion is defined to occur sets the conditions under which parallel imports are permitted. Under international exhaustion, rights to control distribution expire after the first sale anywhere and parallel imports are allowed. Under national exhaustion, only the first sale within a nation exhausts distribution rights and rights holders may prevent unauthorised imports. An intermediate position is regional exhaustion, which permits parallel trade within a group of countries that define a region but prohibits parallel imports from outside the region.

Maskus and Chen (2004:553) report that different countries have adopted different exhaustion rules. The European Union has adopted community exhaustion for copyright, trademarks and patents, meaning parallel imports between countries inside the EU are permitted but are not permitted from outside the EU. The United States maintains a national exhaustion policy for patents and copyright goods, and for trademarked goods with some exceptions. Japan has international exhaustion for trademarks and patents (unless agreed by contract or the original sale was subject to price control), and for all copyright goods except motion pictures. Australia has international exhaustion on trademarks but national exhaustion on patented goods (unless sold without clear restrictions) and all copyright goods except books and CDs. Most developing countries have not restricted parallel trade. ${ }^{4}$

3 McCareins and Neufer (1991) provide a legal commentary on territorial restrictions and their history in a number of US cases, and Posner (1977) discusses per se illegality of vertical restraints in the context of a particular case.

4 See Abbott (1998). 
The literature on parallel importing identifies international price discrimination and freeriding as the two main reasons for parallel importing (Maskus and Chen 1999:11). ${ }^{5}$ The price discrimination theory rationalises parallel importing as the arbitrage of differences in prices between countries. These differences come about because the rights holder has a strategy of tailoring prices to local conditions. Under the free-rider hypothesis, parallel imports are caused by unauthorised distributors utilising investments in marketing and after-sales service by other, licensed, distributors. To date, the empirical literature has considered the discrimination hypothesis in greater depth than it has free-riding.

In contrast to the volume of economic literature which demonstrates the benefits of open international trade (see Wolf 2004 for example), the parallel importing literature is equivocal about the effect of parallel trade on welfare. The empirical literature which examines this question in a price discrimination context broadly concludes that permitting parallel importing is beneficial provided willingness to pay among consumers in different countries is not "too" heterogeneous, and rules on parallel importing should be decided for each industry on merit rather than globally (see Mauleg and Schwartz 1994; Anderson and Ginsburg 1999; Cosac 2003; Maskus and Chen 2004; Valletti and Szymanski 2004). Parallel importing seems to exemplify the tension that exists between intellectual property rights and any enhanced investment incentives on the one hand and gains from immediate competition and trade on the other.

This paper estimates welfare effects of parallel importing when it affects quality. We make use of a natural experiment in the New Zealand film industry which was recently subjected to the introduction and subsequent removal of parallel imported DVDs. The ability to parallel import reduces licensed film distributors' control of various dimensions, in particular timing and variety. The timing dimension arises as the result of the international sequential releases of films in cinemas and on DVD and VHS. Film owners (hereafter 'studios') stagger release dates for a number of reasons, including lowering production costs, and preserving investment options while costly uncertainty is resolved. Parallel importing undermines staggered release because DVDs from early-release countries can be exported to late-release countries, in some cases arriving prior to the film's release in cinemas. Cinema revenues are undermined when consumers substitute viewing the film in cinemas for buying or renting a DVD. The variety of films will be affected by any altered scheduling of films and any effect on the total number of films released over time.

We argue that the introduction of parallel importing will result in shorter delays in the release of films and reduce, to a limited extent, the variety of films in cinemas. However, increased competition under parallel importing will enhance the variety of films made available on other media, and we expect film variety not to diminish overall. Using a natural experiment between 1998 and 2001 in which DVDs were parallel imported into New Zealand for rental, we estimate that for films subject to parallel importing, the substitution from cinema to DVD media caused a statistically significant decline in New Zealand cinema revenues, and that licensed film distributors responded to the threat of parallel importing by bringing forward the release dates of films into New Zealand cinemas. The natural experiment was terminated in November 2001 when it was determined that parallel importation for rental per se was illegal.

5 Hilke (1988:77-83) identifies five causes of parallel importing: free-riding on retailer-provided services, geographic price discrimination by manufacturers, manufacturer efforts to set maximum retail prices, consumer deception, and distributor collusion. Hilke concludes the evidence tends to favour changes in the exchange rate and manufacturer price discrimination as being the principal causes of parallel importing. 
The paper proceeds as follows. In section 2 we outline changes in the regulation of parallel importing in New Zealand in the last decade. In section 3 we describe the essential features of film and DVD distribution in New Zealand, and the means by which parallel importing affects each format. In section 4 we provide a qualitative description of the effects of parallel importing on aggregate surplus produced in New Zealand film distribution. In section 5 we examine the effects of parallel importing using film and DVD timing and revenues data. Section 6 concludes.

\section{A NATURAL EXPERIMENT IN PARALLEL IMPORTING}

By the end of the 1990s, New Zealand had had a long-standing and relatively pervasive policy of national exhaustion for copyright goods. ${ }^{6}$ National exhaustion was effected by defining copyright goods imported without the consent of the New Zealand copyright owner to be infringing. This changed with the passage of the Copyright (Removal of Prohibition on Parallel Importing) Amendment Act 1998 in May 1998. The Act permitted the parallel importing of all copyright goods by replacing the consent of the New Zealand copyright owner (or her agent) with the consent of the overseas copyright owner, effectively substituting international exhaustion for national exhaustion. ${ }^{7}$ In a single unanticipated step, New Zealand had moved from a restrictive to a wholly unhindered parallel importing regime.

The 1998 Act made clear that parallel importing DVDs and VHS tapes into New Zealand for sale was legal, but it was ambiguous as to whether parallel importing for rental was permitted. In spite of this uncertainty (or because of it), parallel imported DVDs began to flow into New Zealand video rental stores in mid 1999, and by 2001 thousands of copies were entering the country for rental. The ambiguity was resolved in a test case in the High Court in November 2001. In Video Ezy (New Zealand) Ltd v Roadshow Entertainment (New Zealand) Ltd, ${ }^{8}$ the High Court held that Parliament did not intend that the scope of the rental rights granted under the Copyright Act 1994 should apply to parallel imported copies of works protected under New Zealand copyright law. ${ }^{9}$ With the legislative ambiguity resolved, the parallel importing of DVDs for rental in New Zealand ceased. Legislation in 2003 extended the right of copyright owners to prohibit the sale of parallel imported films within nine months of the first international release of a film.

A natural experiment is created by the $2 \frac{1}{2}$ year period in which parallel importing of DVD films occurred. The purpose of this paper is to examine empirically the effect of parallel importing on distributors and exhibitors, and consumers.

\section{A. Parallel Importing and the IPR Dilemma}

6 High Court cases in 1996 and 1997 held that the rights of copyright owners were not exhausted even after two or more international sales of goods, meaning second-hand goods imported without consent were infringing. In Composite Developments (NZ) Ltd v Kebab Capital Ltd and Another, CP 174/96, High Court, Auckland 10 May 1996 (Salmon J) the plaintiff successfully sought to restrain the importation of second-hand skis and snowboards of French manufacture and design. In Lyntec Holdings Ltd v Wills, Unrep, CP 11/97, High Court, Auckland, 29 January 1997, (Robertson J), new and second-hand jet skis had been imported, with both types being deemed to have breached the 1994 Act.

7 Section 12(5A) b.i appeared to allow unauthorised copies to be imported into New Zealand. Under subpara (i), once the copyright has expired in the exporting country any third party can import into New Zealand unauthorised copies without infringing copyright. With some countries not bound by international obligations, it appeared the door had been left open to an individual country to grant only a limited term to copyright and, once that copyright has expired, any unauthorised copyright goods may be manufactured and legally exported from that country to New Zealand.

8 [2002] 1 NZLR 855, (2002) 7 NZBLC 103, 524.

9 Andrew Brown provides a useful summary of the case at $h t t p: / / w w w . a n d r e w b r o w n . c o . n z /$ recent/videoezy.asp 
There is no consensus in legal or economic scholarship on the desirability of parallel importing. The utility of parallel importing depends on whether monopoly rights on production conferred under copyright are usefully extended to alienable monopoly rights on distribution between, but not within, countries. Answering this question requires a definitive position on, firstly, whether the benefit of extending a monopoly intellectual right outweighs the benefit of unhindered inter-country distribution of goods, and secondly whether inter-country trade is the appropriate level of granularity since other levels (relating to the movement of goods between individuals, for example) are theoretically possible.

The optimal treatment of parallel importing is part of a wider question on the optimal scope of intellectual property rights. Lemley (2004) summarises the position on this issue as follows:

The proliferation of economic literature on intellectual property over the last two decades has improved our understanding of the economics of innovation and intellectual property considerably, but it has not given us a magic bullet or told us where to draw the line between protection and the public domain. Instead, it has taught us that there is no one right answer. The optimal scope, strength and duration of intellectual property protection depend on the type of creation at issue, on the nature of innovation in the particular industry in question, on the particular kind of invention (and inventor) at issue, and on the market context. They may also depend on the sort of information that is at issue. The problem is further complicated by the fact that we must take into account other means intellectual property owners have of enforcing rights, including contract and technological protection. Given this, it is hard - and perhaps even impossible - to ever calibrate intellectual property law perfectly.

The relationship between intellectual property rights and welfare is commonly visualised as an inverted ' $U$ ', where the horizontal axis is the extent of protection offered by intellectual property rights. At one extreme on this axis, there is no protection of intellectual property rights, the economic incentives for innovation are diminished, and welfare is low. At the other extreme, broad intellectual property rights that are strongly enforced discourage innovation by raising the cost of original expression. These costs include the effort required to search for previous creative inventions to ensure the expression is original, as well as impairing access to existing ideas useful to the creation of new ideas. The social value of parallel importing will almost certainly lie between these extremes.

Because parallel importing is frequently the result of price differences (Hilke 1988), there has been economic analysis of parallel importing in the context of price discrimination. The question of whether parallel importing restrictions are desirable is transformed to a question of whether international third degree price discrimination, which it is assumed parallel importing undermines, is desirable. ${ }^{10}$ However, even in this framework estimating the welfare effect of parallel importing is difficult because, except in special circumstances, the welfare effects of price discrimination are ambiguous and require quantification in order to reach a view. ${ }^{11}$ Empirical studies of parallel importing in a price discrimination framework have come to varying conclusions about the effect of

10 Third degree price discrimination occurs when different prices are charged for the same good on the basis of customer characteristics.

11 Carlton and Perloff (2000:290). A concrete result to emerge from the discrimination literature is from Varian (1985) who shows that a necessary condition for price discrimination to raise welfare is that total output increases; but this relates to an homogeneous good. The difficulty and the importance of measuring the welfare effects of the introduction of goods with new qualities are discussed by Hausman (2003). 
parallel importing on welfare. Maskus and Chen (1999) maintain the net benefit of parallel importing depends on the specific circumstances, and argue policymakers should adopt a rule of reason approach.

The difficulty policymakers have had in locating the optimal bundle of property rights granted to innovators is reflected in various attempts either to preserve the status quo, ${ }^{12}$ or to draw arbitrary distinctions in the treatment of parallel importing. There is, for example, no automatic distinction in economics between the sale and rental of durable goods. Renting is simply a special form of sale of services, an agreement to re-sell the good back to the renter at a price agreed in advance. Yet different treatment for parallel imported goods depending on whether they are used for rental or sale is enshrined in both the TRIPS agreement and New Zealand legislation. ${ }^{13}$ The lack of distinction between renting and sale is epitomised in the difficulty negotiators of the TRIPS agreement had when attempting to define the term "rental", as the following draft definition illustrates: 14

... rental shall mean the disposal [for a limited period of time] of the possession of the original or copies for [direct profit-making purposes][direct or indirect commercial advantages].

The square bracketed sections denote the parts of the definition to be negotiated. The definition was ultimately abandoned and although Article 11 of TRIPS is directed at renting, the final version of TRIPS does not define what renting means. ${ }^{15}$ The arbitrary legal distinction between sale and rental helps define the natural experiment we use in this study.

\section{NEW ZEALAND FILM DISTRIBUTION}

The New Zealand final consumption cinema industry is relatively successful. In 2002 New Zealand had the fifth highest cinema admissions per capita in the world. ${ }^{16}$ New Zealand real box office revenues increased 34\% between 1997 and 2003; 2000 was the only year in this period in which revenues declined. ${ }^{17}$

Cinematic distribution of films in New Zealand is carried out by twelve distributors, a mix of subsidiaries and local agents of overseas studios. Film distributors do not have a financial interest in New Zealand cinemas. Cinemas retain $55-60 \%$ of box office revenues and distributors receive the balance, from which the costs of importing are funded. ${ }^{18}$ The decision to distribute a film domestically is made by local distributors, subject to studio approval. Distributors group cinemas into three tiers (city, suburban, and provincial) and have standard revenue recovery percentages from each group. These rates are negotiable.

Local distributors obtain film prints at cost. A new print costs approximately US $\$ 2,500$

\footnotetext{
12 The introduction of legislation restricting parallel importing of DVDs, was specifically directed at protecting New Zealand cinema chains from parallel importing. It was instigated by evidence presented to the Minister that parallel importing had had a demonstrable effect on cinema revenues.

13 World Trade Organisation (WTO) Agreement on Trade-Related Aspects of Intellectual Property Rights.

${ }^{14}$ Negotiating Group on Trade-Related Aspects of Intellectual Property Rights, including Trade in Counterfeit Goods, "Status Of Work In The Negotiating Group: Chairman's Report to the GNG," MTN.GNG/NG11/W/76, 23 July 1990. Available from http://www.ipmall.info/hosted_resources/trips/W76.pdf

15 We thank Warwick Rothnie for his input in this section.

16 Source: Australian Film Commission http://www.afc.gov.au/gtp/acompadmitper.html

17 Source: Columbia Tristar.

18 Source: Columbia Tristar.
} 
plus shipping. ${ }^{19}$ A second-hand print is obtained by local distributors for only the cost of shipping.

Films are sequentially released on to various formats, with cinema generally being the first. Subsequently, films are released on DVD/VHS for sale and rental (3 to 6 months after cinema release), pay-per-view television ( 7 to 9 months later), pay TV (12 months later) and finally free-to-air television (minimum 24 months later) ${ }^{20}$ Studios employ sequential release of films on different media and strategic pricing, in which the price of access to films falls with time after release, as strategies to maximise net revenues. ${ }^{21}$

Local distributors are selective in the foreign films they distribute. Approximately $25 \%$ of films shown in US cinemas are not selected for cinematic release in New Zealand. ${ }^{22}$ The constraint on local cinematic release is expected profitability, not limited available screen space. Expectations of profitability take into account the marketing exposure that cinematic release has on subsequent DVD sales and rental.

Studios stagger the international release of films and obtain three benefits from this. First, delay permits a substantial saving by using second-hand film reels. The cost of new film prints constitute the largest cost item of a "day and date" (i.e. no delay) cinematic release. ${ }^{23}$ Quality problems with second hand reels occasionally occur, but in general used film reels are of substantially the same quality as new film reels.

Second, inter-country staggering of releases informs expectations about the commercial success of a film which is substantially (but not entirely) resolved when overseas performance is observed. Third, staggering permits the management of local release times to avoid inter-film conflict and coincide with local holidays and seasons, thereby raising revenues.

Delay is not without cost, however. Staggered release dates mean contributions to fixed production costs arrive later, which is costly. They also increase opportunities for piracy, which, depending on the country, is a major concern for studios and distributors.

Not all cinematic releases are staggered. Major blockbusters and films deemed to carry a strong likelihood of success will be released in a number of countries at about the same time as in the US. Day and date release occurs when marketing spillover effects are deemed strong enough to justify foregoing the benefits of delay.

Video and DVD rental distribution occurs via a number of independent chain video stores. Studios supply video stores under two distribution models. Under one model, video stores purchase DVDs outright. Under the second model, a revenue sharing arrangement is instituted. Studio distributors supply VHS and DVD releases to rental stores at no charge and collect a percentage of rental fees. Because royalties are paid only when rental occurs, risk is shared, and any financial constraint for the video rental store alleviated. More copies are available for renting and consumers benefit from reduced congestion and waiting times.

\footnotetext{
19 http://www.michaeldvd.com.au/Articles/FutureOfCinema/FutureOfCinema.html

20 Source: Columbia Tristar. Many films are released directly to DVD or VHS and not shown in cinemas.

${ }^{21}$ Varian (2000) shows that offering rental and for-sale versions of information goods such as films can raise profits (and welfare) by allowing distributors to reach "poor" consumers via rental and "rich" consumers via purchase. Rental is a means of reaching consumers who would otherwise go unserved. Interestingly, Varian notes the initial opposition of film studios to home video rental.

${ }^{22}$ Source: Columbia Tristar. According to Columbia, the constraining factor on films shown in New Zealand is not the limited number of screens but profitability. An instance where a profitable film has been unable to be shown as a result of unavailability of screens has not occurred.

${ }^{23}$ Source: Columbia Tristar.
} 


\section{A. Effect of Parallel Importing on Film Distribution}

When parallel importing is permitted, staggering the release dates of films into cinemas and subsequently on to other formats creates an arbitrage opportunity that is depicted in Figure 1.

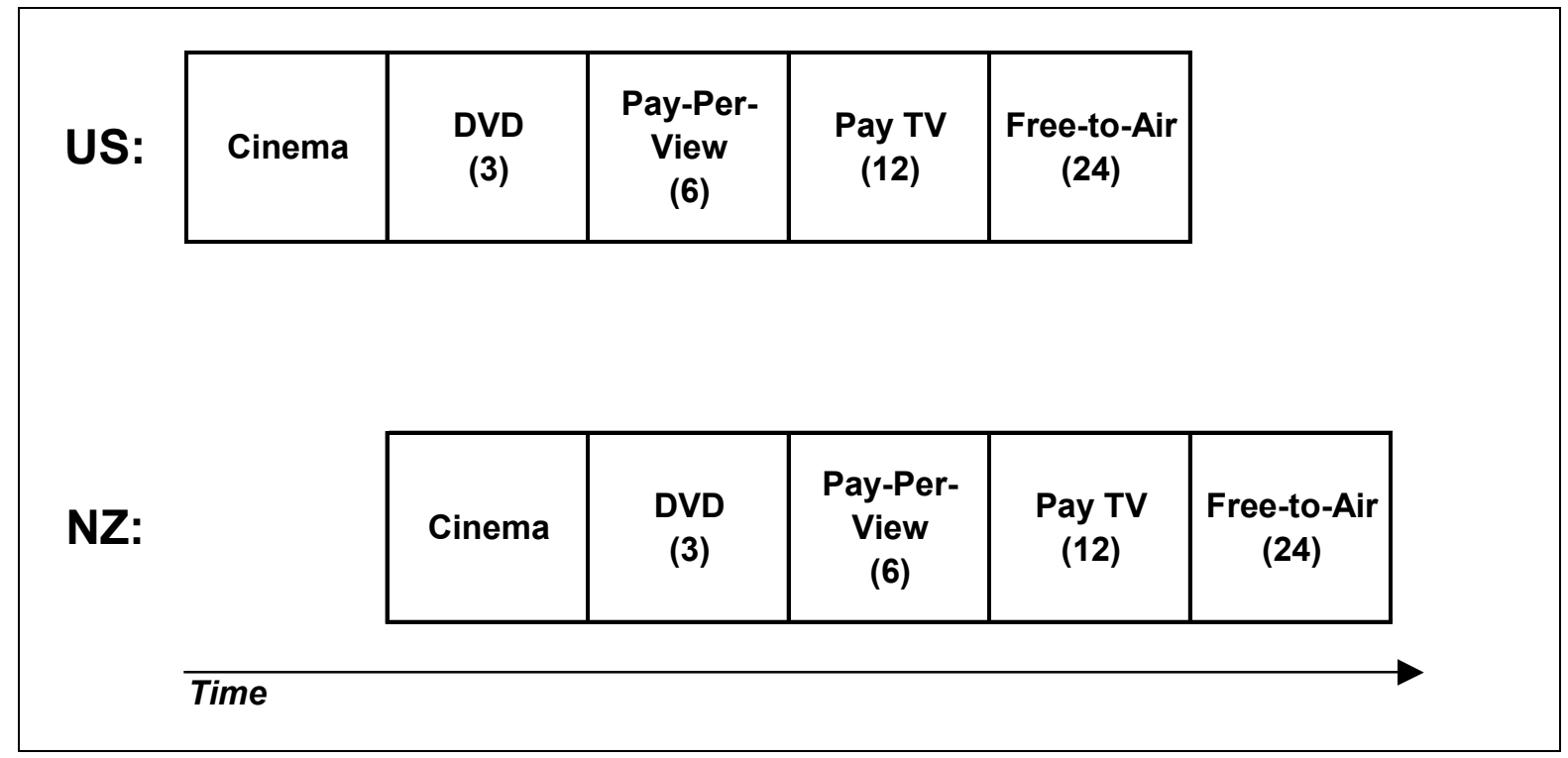

Figure 1. Release is Staggered by Media Type and By Country (Approximate Months Delay in Brackets). ${ }^{24}$

Figure 1 shows that the cinema release of a film will be followed by the DVD version of the film approximately three months later. In the example, the US DVD release date coincides with the New Zealand cinema release date. When parallel importing is permitted, the US DVD may be imported to New Zealand, and appear in New Zealand rental stores as the film is released in cinemas. The DVD is a substitute format to viewing the film in cinemas. Parallel importing reduces studios' ability to profitably stagger the international cinematic release of films because of competition from (legitimately produced) DVD and VHS copies of a film from an early-release country which may be imported into a late-release country before the official release of these films on that format in the receiving country. ${ }^{25}$ If parallel importing of the kind shown in Figure 1 is pervasive then, if lobbying the government for protection from parallel importing is unsuccessful, studios may find it profitable to reduce arbitrage opportunities by limiting either (or both) international staggering and format staggering.

Among the mainstream films we surveyed, the United States is, on average, the first to exhibit a film. ${ }^{26}$ Figure 2 compares the average number of days that films are staggered relative to the US. In New Zealand, $31.9 \%$ of films released locally occur more than four months after the US cinema release date and $17.8 \%$ occur more than six months later.

\footnotetext{
${ }^{24}$ Home video or VHS release usually coincides with the DVD release, not represented here because VHS is not parallel imported, for reasons we discuss below.

25 By "official" we mean the release date as decided by the rights owner or her agent in that country.

26 Marvasti and Canterbery (2005) report the number of films produced by country in 1991-1995, The number produced by the USA was markedly in excess of all countries except India which produced 827 per annum. In the same periood they report that New Zealand averaged 5.2 per annum.
} 
There is an implied arbitrage opportunity for DVD parallel imports from the US into New Zealand for between a third and a sixth of all movie releases, because the time between cinematic and DVD release of a film averages three months.

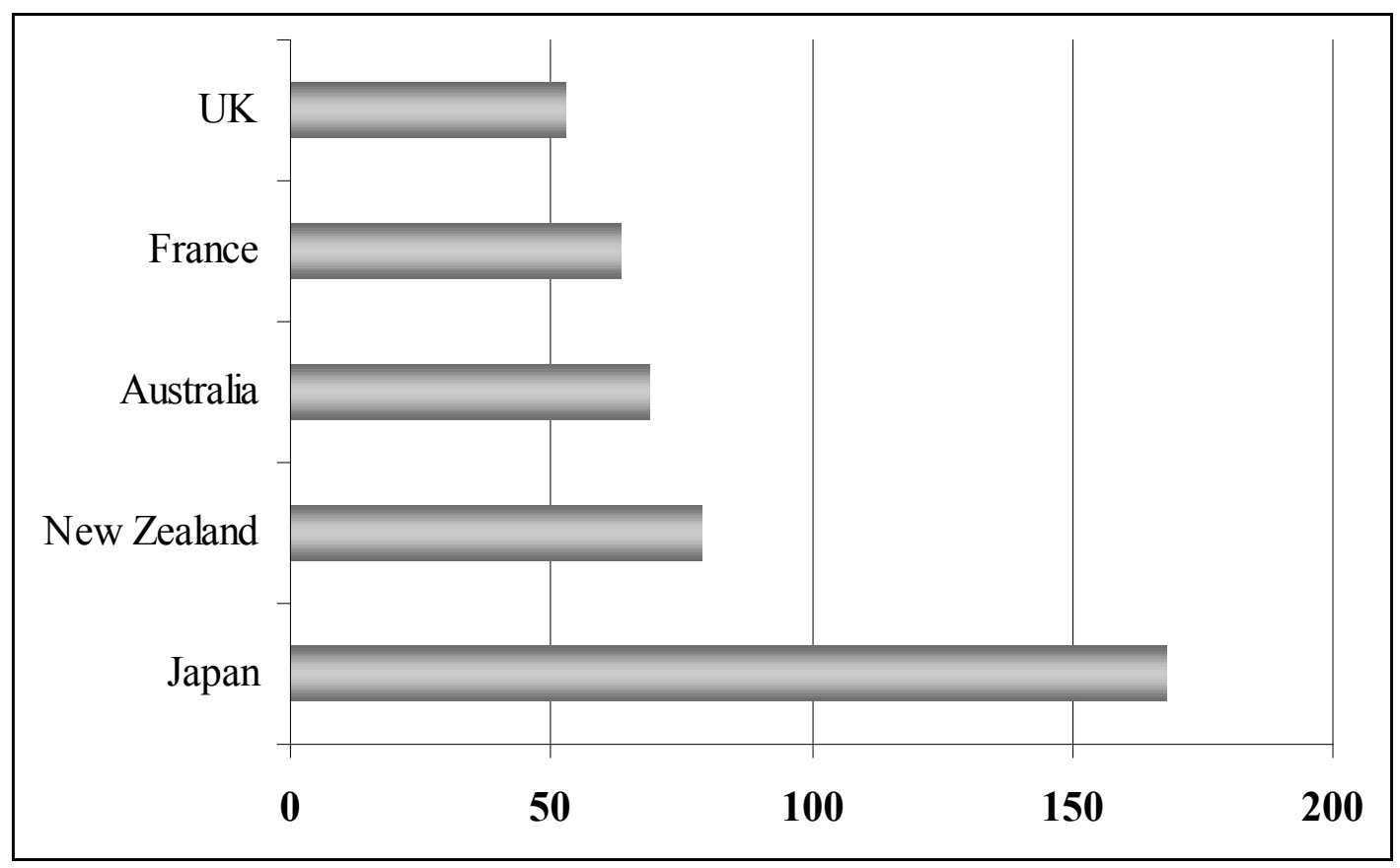

Figure 2: Average Number of Days Delay After US Cinematic Release. Source: www.imdb.com.

Data on New Zealand box office revenues 1997-2003 indicate the impact of parallel importing was significant. The parallel importing of DVDs, which peaked in 2000 and 2001, appears to have strongly affected cinematic box office revenues. Figure 3 shows that New Zealand cinemas experienced a sharp reduction in box office receipts in 2000: real revenues fell 13\% compared to 1999 mostly as a result of lower admissions; real prices were relatively unaffected. Revenues increased sharply in the year following the cessation of parallel importing in November 2001. 


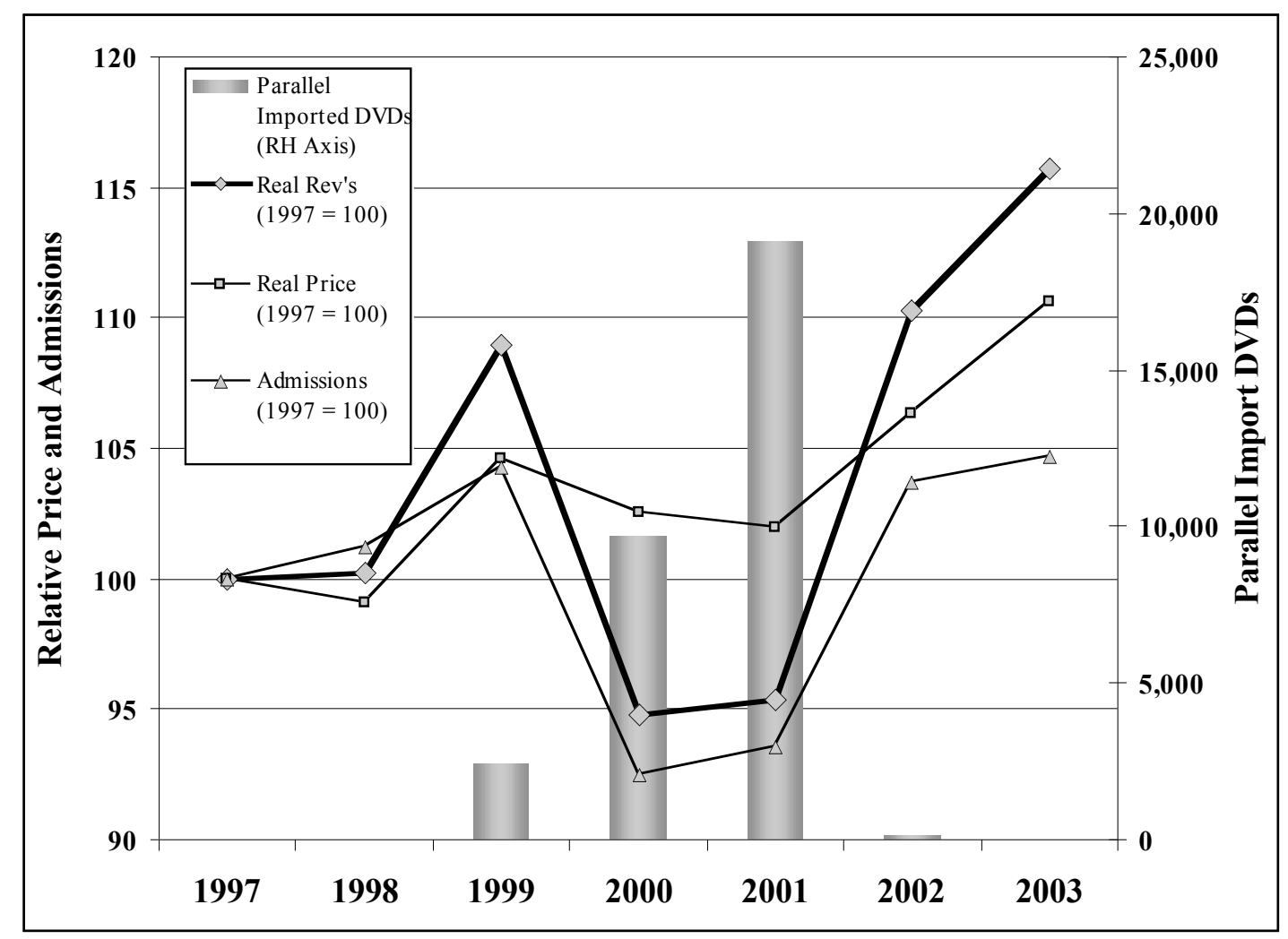

Figure 3: Real Box Office Revenue and Price and Admissions 1997-2003 (1997=100). Source: New Zealand Film Distributors Association, DVD World. ${ }^{27}$

The apparent effect of parallel imported DVDs on cinema admissions occurred in spite of three factors which inhibit the availability of parallel imported DVDs. ${ }^{28}$ First, the revenue sharing arrangement between authorised distributors and video rental outlets is not available for parallel importers. Parallel imported DVDs must be purchased from overseas wholesalers outright, and thus options for financing supply and the sharing of risk are limited. This constrains the quantities of DVDs on rental store shelves to only a few copies - perhaps only one. ${ }^{29}$ Secondly, New Zealand censorship laws require that the first imported copy of a film on each format must obtain a censor's rating at a fixed price of NZ\$1,500 per film. Where parallel imports of DVDs are first to market in that format, the importer is required to pay the censor's fee. The limited volumes of parallel imports of each film, a result of the lack of revenue sharing, mean the censor's fee constitutes a

\footnotetext{
27 Excludes revenues and admissions from the Lord of the Rings trilogy. These films were produced in New Zealand and are the first, second and fourth highest grossing films in New Zealand cinema history. They were an anomalous or one-off source of revenue in 2001, 2002 and 2003 and therefore excluded. These films were released into domestic cinemas "day and date" with overseas cinemas and are therefore not affected by parallel importing. The exclusion of the trilogy raises a question about substitution, in particular whether the reduction in cinema revenues in 2000 and 2001, as shown in Figure 3, reflects substitution away from other films and towards the excluded trilogy. This seems unlikely: revenues were depressed before the arrival of the first film in the trilogy and recovered the year after the release of the first film in 2001. This is consistent with the effective abolition of parallel imported DVD rentals at the end of 2001, and not with the exclusion of the trilogy.

28 In section III we formally test the effect of parallel importing controlling for the quality and timing of released films.

${ }^{29}$ Source: DVD World, the principal parallel importer of DVDs in New Zealand between 1998 and 2001.
} 
significant hurdle..$^{30}$ A third disadvantage is that parallel imported DVDs generally ship with out-of-region encoding meaning that an all-region DVD player is required to view the DVD. ${ }^{31}$ The express purpose of the regional encoding system is to segment the world and protect the staggered cinematic release of films (Gans, King and Dunt 2001:4). The increasing availability of all-region DVD players has undermined this impediment.

\section{COSTS AND BENEFITS OF PARALLEL IMPORTING}

In this section we compare the various costs and benefits that studios, distributors and consumers of films bear with and without parallel importing. The costs and benefits of parallel importing in the film industry are determined by the producer and consumer behavioural responses that parallel importing induces. We classify the costs and benefits of parallel importing as falling into the following categories.

- Utility arising from timing of the availability of films to consumers;

- Utility arising from the variety of films available to consumers;

- The price of film consumption to consumers;

- The investment in film provision to consumers over time; and advertising to inform consumers about films;

- $\quad$ Profits of studios and their distributors, which are determined by:

- $\quad$ production and distribution costs; and

- $\quad$ revenue earned on a film via various media.

We presume that consumers prefer to view films as close to release dates as possible, a view we justify below. We maintain that New Zealand parallel import policies will not affect the supply of films from any country. New Zealand is a very small market and its policies towards film release will negligibly affect revenues from films produced in any country. Adverse effects on investment in New Zealand-produced films are only likely if a parallel import ban can be expected to diminish revenue from such films, since it may be assumed that production costs will not be affected. New Zealand is a very small country and successful films produced there rely on international consumption for their success: clearly this opportunity will not be diminished by parallel importation policy which affects only the means by which overseas films are released locally. Under parallel importation, all New Zealand made and oriented films may have to compete in the local market with a wider variety of more timely releases of foreign films at potentially lower cost. It is unlikely that this would generate any more competition for New Zealand oriented films because such films are differentiated from films made in other countries. Indeed, for such films to be of benefit to consumers in the short and long term, they

\footnotetext{
30 Records obtained from DVD World shows that 41,993 copies of 307 films were imported during this period. On these amounts, and assuming a censor's fee was payable on each title, the censor's fee of NZ $\$ 1,500$ would average NZ $\$ 10.97$ per copy. This is significant when the retail price of a new DVD is around NZ\$40 (including GST). For $45.9 \%$ of titles, less than fifty copies were imported and in this sample the average censor's fee, if payable for each title and assuming compliance, is $\$ 87.90$ per copy.

31 The DVD format is designed with a coding system that divides the world into six regions. As examples, the system places USA and Canada in Region 1 and Australia and New Zealand in Region 4. The region coding system requires that each country is provided DVDs and DVD players specific to that region. Region-specific DVD players will not play a region-incompatible DVD, precluding, in principle, parallel imports between regions. This system is undermined by all-region DVD players which permit DVDs of any region to be viewed.
} 
should pass this test of competition. ${ }^{32}$ Protecting local film production by means of parallel importing restriction is analogous to a tariff, a particularly inefficient form of protection. Even if greater local production is considered a priority by government, other policy options with superior efficiency exist (Carlton and Perloff 2000:581-2). We presume that production incentives for New Zealand made and oriented films need not be considered in our welfare assessment.

\section{A. The Delay Option}

A temporal monopoly in the introduction of a film to a market confers an option to delay the issuance to a date that maximises expected net revenue. This delay is valuable as it confers net benefits when there is investment under uncertainty and at least some irreversibility of investment (Dixit and Pindyck 1994). Irreversibility arises when investments are sunk and not recoverable, once made. They are present when a film is released and in film promotional expenditures. The option to delay is likely to be relevant in varying degrees in most industries affected by parallel importing. To our knowledge, the empirical literature has not conducted an explicit assessment of parallel importing where timing is an important element of quality. Assuming that the production of films is unaffected the welfare effects of the option to delay materially affect the desirability of parallel importing. A ban on parallel importing attenuates film-specific monopoly supply and promotes competitive media.

The real options literature suggests that monopoly firms invest later than is socially desirable because they do not include in their profit consumers' surplus relating to their investment. Competition brings forward investment in the presence of options to delay as firms pre-empt investment by others. However, the literature is still evolving. Lambrecht and Perraudin (2003) find in their model (based on a basic investment timing option, modified so that two firms compete for the right to move first and capture the whole market; firms know their own cost structure, but not their competitor's) that the delay option can be worth anything between zero and the usual monopolistic option value. In contrast, Grenadier (2002) looks at the effect of competition on firms' investment timing options and finds that the option value falls to zero. Novy-Marx (2004) argues that Grenadier's result follows from his assumption that the production technology is linear and incremental. These are standard assumptions under perfect competition and are hardly met in the film distribution industry, where there are considerable scale economies in information goods and advertising. In an equilibrium model Novy-Marx discovers that competition can actually elevate the value of firms' investment timing options above the monopolistic option value, possibly increasing incentives to delay. Dixit and Pindyck (1994, chapter 8) find that competition reduces but does not eliminate the (option) value of waiting compared to monopoly.

In short, under a parallel import ban of films suppliers are less competitive in distribution and they may wait perhaps too long to invest relative to the welfare optimum delay, because they share investment surplus with consumers. ${ }^{33}$ However, competition between films may provide sufficient risk of costly pre-emption so that investment occurs at an approximately optimal time; although, in the case of films, laws protect studios from

\footnotetext{
32 Marvasti and Canterbery op cit, explain the enigma of the USA's dramatic film export performance, in the presence of no barriers to entry of films to the USA, but barriers to export, to economies of scale, English language and the qualities of stars. They argue that export revenues, including those of DVDs, approached domestic revenues in 1999; and that the export revenue was essential to the survival of a number of USA studios.

${ }^{33}$ Based on the total surplus standard of producer plus consumer surplus.
} 
unauthorised public showings and no inter-firm competition for the cinematic release of a film can occur.

In the presence of a parallel importing ban there remains competition between films and this may induce the optimum delay. It may mean that increased competition (under an international exhaustion rule), investment may occur too soon relative to a welfaremaximising optimum because firms attempt to avoid costly pre-emption.

In sum, while the real options provides a suitable framework for assessment of whether competition (parallel importing) or monopoly will optimise welfare, it does not make general statements about the relative performance of competition versus monopoly, and the net benefits of parallel importing are likely to be industry-specific. From a policy perspective, a rule of reason approach may therefore be preferred to global rules about this form of importing.

The following analysis assumes that the staggered release of films around the world requires effective separation of markets and that this staggering is undermined by parallel importing. The welfare effect of parallel importing is thus given by a comparison of welfare without and with staggered release dates.

\section{B. Effect of Parallel Importing On Delay and Variety}

Consumers value variety because it increases the opportunities for the available mix of goods to match their heterogeneous preferences. ${ }^{34}$ The net effect of parallel importing on film variety is potentially ambiguous. It is possible that the variety of films released in cinemas will decline for the following reason. Box office revenues on delayed films are reduced by competition from parallel imports. When "day and date" release of a film is uneconomic on costly new film reels, and delayed release of that film is made uneconomic by parallel importing, that film will not be released in cinemas and the variety of cinema releases declines. However, we expect increased media competition and lower costs of provision under parallel importing will increase the variety of films on other media formats, and may induce a competitive reaction in cinematic film variety. On balance we expect film variety not to diminish under parallel importing. ${ }^{35}$

Figure 4 shows the number of films released in New Zealand per year. There were two consecutive reductions in the numbers of films distributed in 2001 and 2002 followed by a record high number of cinematic film releases in 2003. Unfortunately, Figure 4 does not inform changes in variety because the rate at which films are released also depends on delay, which we have shown changed substantially during and immediately after the sample period. The reduction in film releases in 2002 as shown in Figure 4 is consistent with an increase in average delay immediately after parallel importing ended as shown in Figure 5: we expect a lower density of films during the period of transition from short average delay to longer average delay which occurred following termination of parallel importing in November 2001. Accordingly, our data cannot inform us of the effect of parallel importing on film variety in cinemas.

\footnotetext{
34 Krugman (1979) provides the seminal work on the efficiency implications of variety. Broda and Weinstein (2004) estimate the welfare gains from growth in import varieties between 1972 and 2001 constitute 2.8 percent of US GDP.

${ }^{35}$ A reduction in the variety of films released into cinemas does not automatically imply a net reduction in welfare. We argue parallel importing is likely to be associated with an offsetting increase in variety of films on other media formats, and we demonstrate it is associated with shorter delays in cinema release. These improvements are valuable, and in our view almost certainly outweigh the costs.
} 


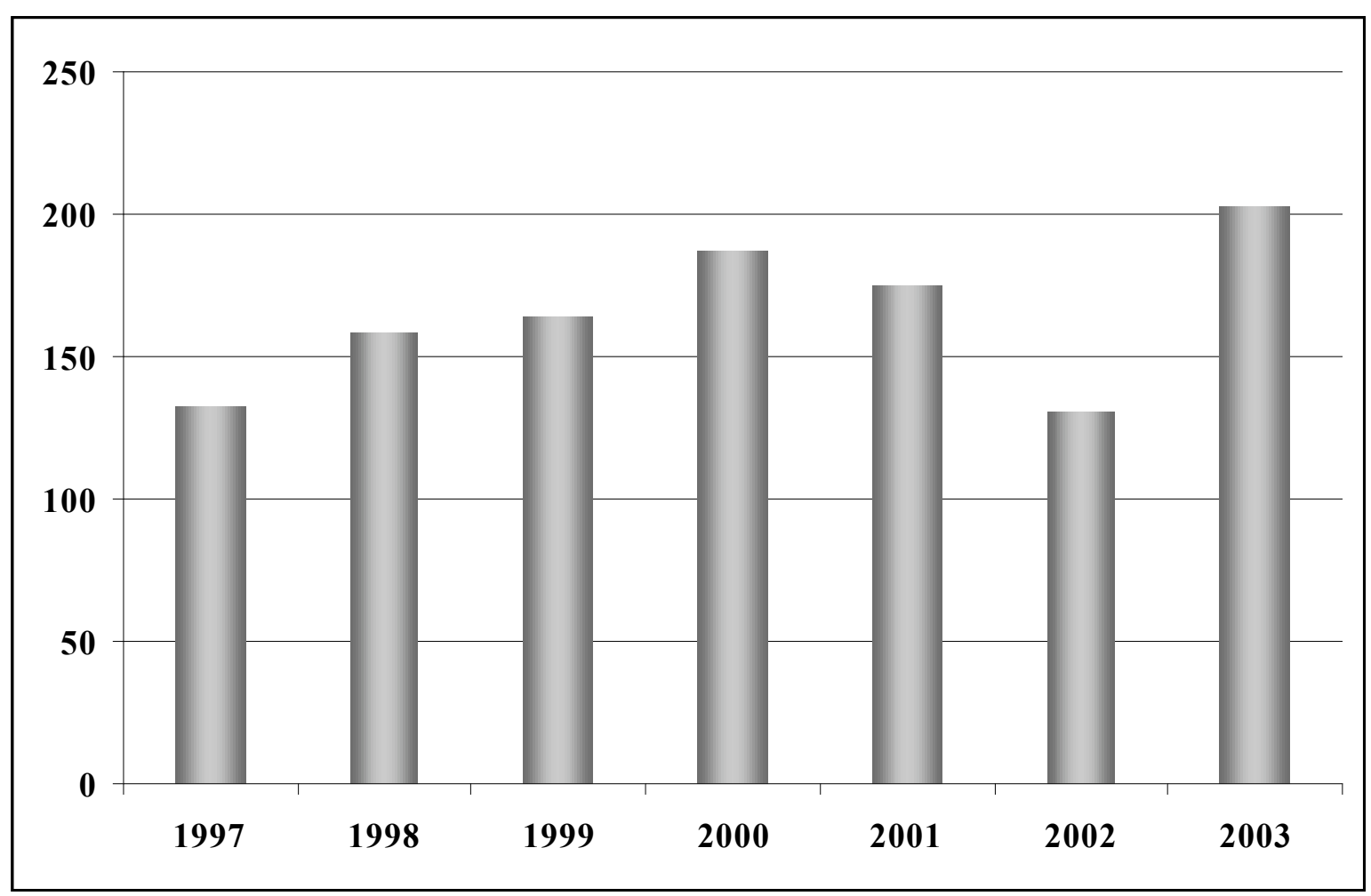

Figure 4: Number of Films Released in New Zealand Cinemas 1997-2003. Source: Motion Picture Distributors Association. ${ }^{36}$

Parallel importing reduces delay (see Figure 5) because films which are delayed are threatened by the early arrival of parallel imported DVDs. Films released approximately "day and date" with overseas first release avoid this threat entirely.

${ }^{36}$ Includes films released by independent distributors. In 2003, 42\% of films were released by independents. 


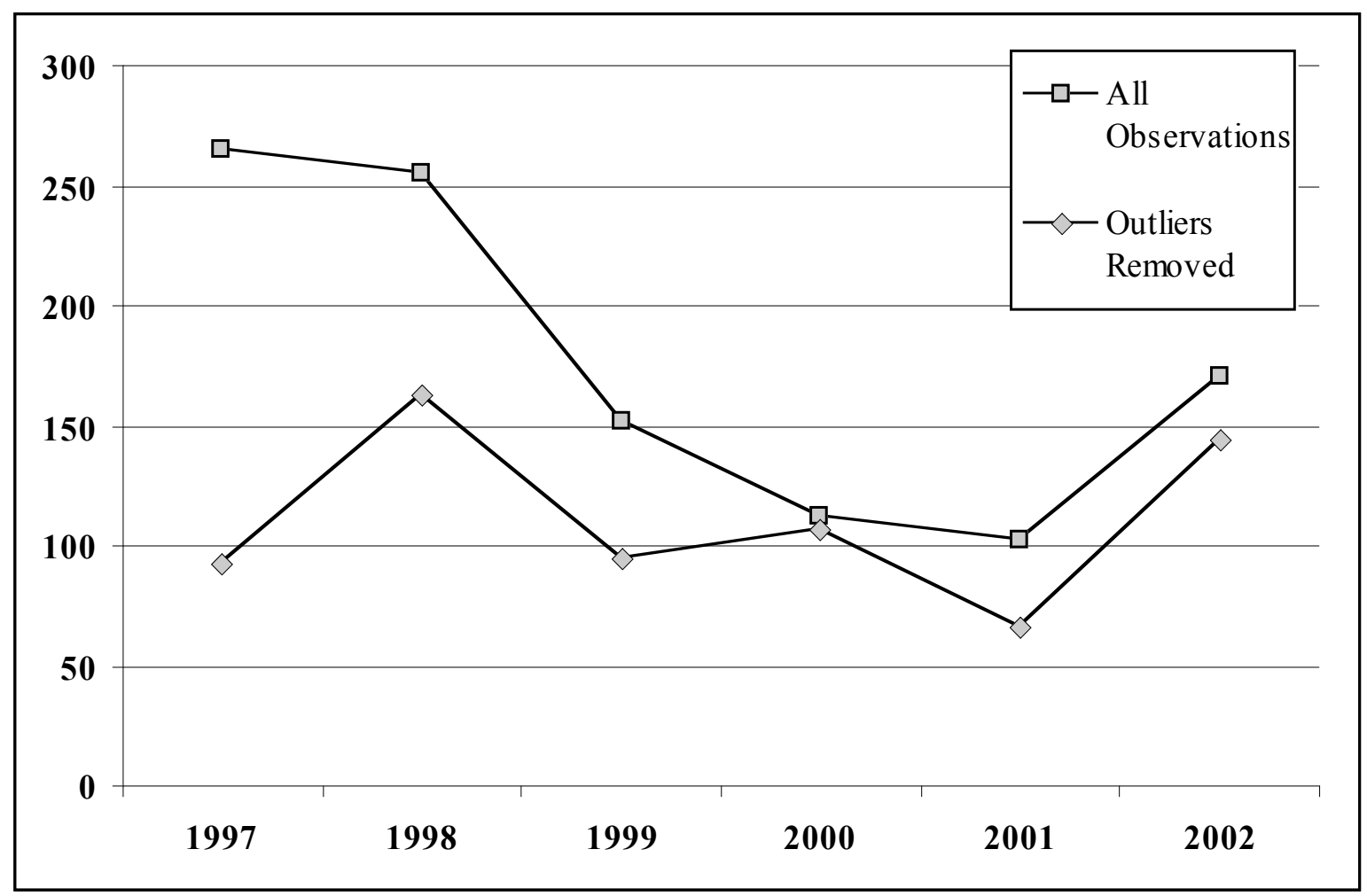

Figure 5: Average US-NZ Days Difference In Release Dates 1997-2002.37

Both our theoretical and empirical results (described below) indicate parallel importing reduces the average delay in the domestic release of films by increasing the cost of delay for distributors. That consumers value consumption sooner rather than later is standard in consumer theory. ${ }^{38}$ However, early consumption seems particularly important in the consumption of information goods such as films. The natural experiment of parallel importing of DVDs into New Zealand between 1998 and 2001 demonstrates the proclivity for consuming films soon after release. Parallel imported DVDs arrived in video rental stores at approximately the time of a film's release in cinemas attracted substantial premiums. Whereas new release DVDs that arrived 3 to 6 months after cinematic release rented for $\$ 7$ a night, parallel imported DVDs made available during a film's run in cinemas rented for $\$ 10$ a night. Renters of these parallel imported DVDs were willing to pay a premium of $40 \%$ knowing that the rental price would be reduced to $\$ 7$ in a matter of weeks. This indicates that, for some consumers at least, the cost of delay is substantial.

Parallel importing may also affect the marketing decisions of film distributors. Consumers value marketing as a means of reducing search costs. If parallel importing of DVDs reduces box office earnings on late-release films, then the marginal revenue earned

\footnotetext{
37 Outliers are defined as having an absolute delay exceeding one year.

${ }^{38}$ Individuals have personal discount rates that weight consumption in the present more heavily than in the future. The personal discount rate is measurable. A recent study by Warner and Pleeter (2001) looked at a US military drawdown program in the early 1990s. On separation from the US military, officers could select either lump sum payment or an annuity. Officers' personal discount rates can be inferred from their selection, and it was found that these selections were consistent with discount rates of between $17.5 \%$ and $19.8 \%$. This is well in excess of normal investment discount rates, and implies individuals value the future relatively little. In other words, individuals attach a relatively high cost of delay. Warner and Pleeter also report on previous studies in the past 25 years have found personal discount rates ranging from $1 \%$ to $243 \%$. They also report studies found hyperbolic discount rates (higher discounts attached to short delays).
} 
on advertising is reduced, and optimal marketing expenditure will decline.

We have not been able to obtain data on marketing expenditure by New Zealand film distributors, but film distributors have advised us that while no formal adjustment to marketing expenditure occurred in response to parallel importing, a reduction may have occurred had parallel importing of DVDs for rental continued beyond November 2001.

\section{QUANTIFYING THE EFFECT OF PARALLEL IMPORTING}

After a sustained increase in (real) box office revenues, New Zealand distributors reported a reduction in 2000, the first year that parallel importing of DVDs became significant. The reduction was attributed to the substitution of parallel imported DVDs sold or rented to consumers. We test whether parallel importing significantly affected box office revenues after controlling for film quality and timing. We also investigate whether parallel importing was associated with a shortened cinematic release delay. That there was some timing effect is strongly suggested by Figure 6 .

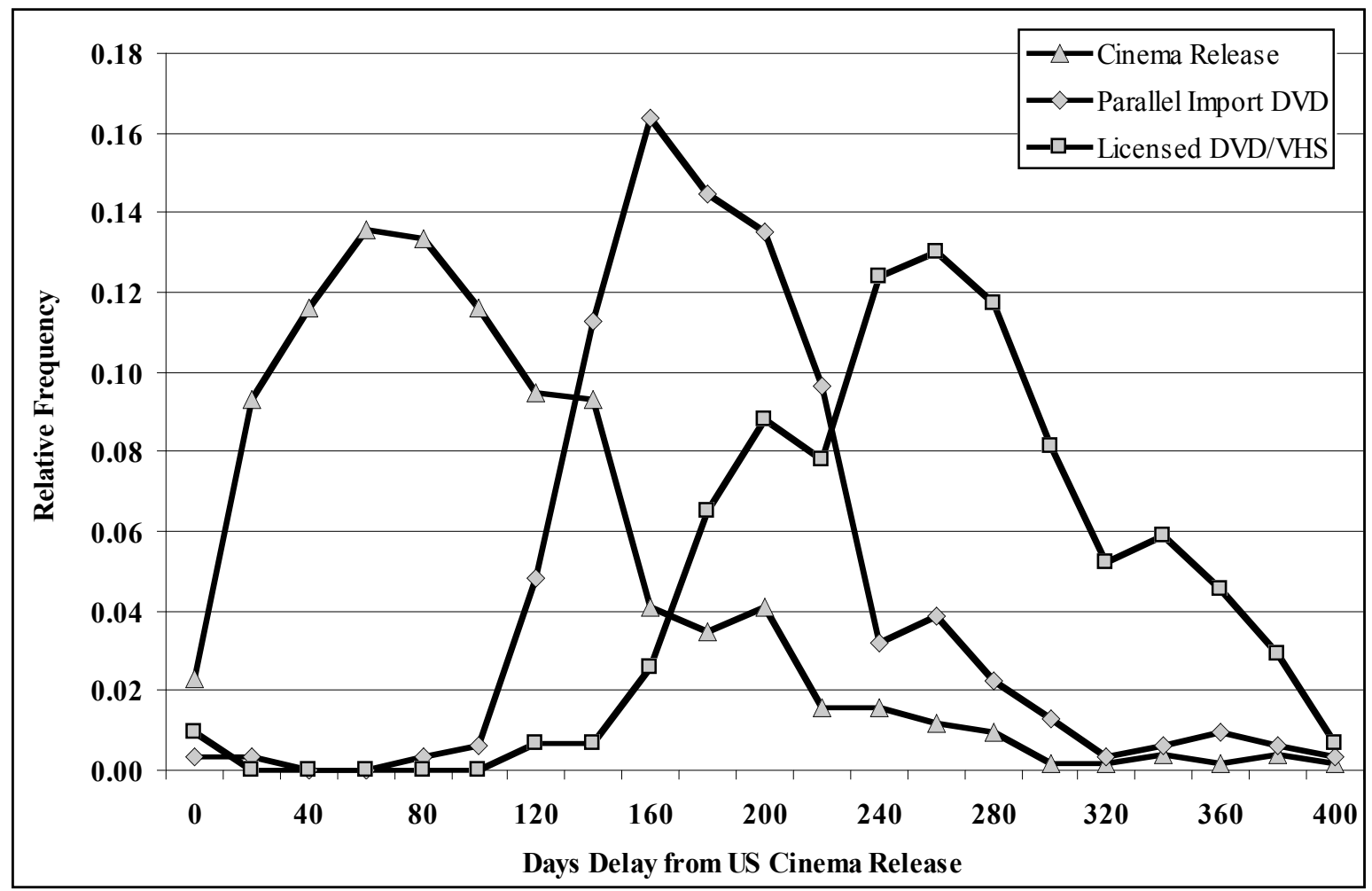

Figure 6: Relative Frequency of Days Delay from US Cinema Release: New Zealand Cinema, Parallel Import DVD and Licensed DVD Releases (1997-2002). ${ }^{39}$

39 Outliers have been removed from these distributions for clarity. Removed outliers represent $1 \%$ of the Cinema Release distribution, 14\% of the Parallel Import DVD distribution, and 7\% of the Licensed DVD/VHS distribution. Outliers are included in statistical testing. 
To test the effect of parallel importing on box office revenues, we specify the following model: 40

$$
R_{i}^{N Z}=\alpha+\beta R_{i}^{U S}+\chi P I_{i}+\delta P I_{i} \cdot D_{i}+\phi E_{i}+\varepsilon
$$

where $R_{i}^{N Z}$ is New Zealand box office revenue of film $i$, $R_{i}^{U S}$ is US box office revenue of film $i$, $P I_{i}$ is a dummy indicating whether there is record of film $i$ being parallel imported on DVD format (=1 if parallel imported), $P I_{i} \cdot D_{i}$ is the product of dummy variable $P I_{i}$ and

$D_{i}$ which is the number of days between New Zealand cinematic release and parallel import release date; and

$E_{i}$ is the number of days between US and New Zealand cinema release of a film.

The US box office revenue controls for the entertainment value of the film. We expect the sign of the coefficient on this variable to be positive and near unity if the tastes of the US populace are similar to those of New Zealand. In accord with our hypothesis of the effect of parallel importing on the monopoly media, we expect a negative sign on the dummy variable PI. The interaction effect of delay and revenue (PI.D) we expect to be positive in that a parallel import that arrives later has a less-negative effect on cinema revenues. The coefficient on the delayed release variable E could be either positive or negative. If longer delay tends to make local release dates coincide with holidays and long weekends then a positive coefficient is expected. On the other hand, long delays may quell demand for a film; and hence longer delay may be associated with a reduction in revenue. ${ }^{41}$ The data sources are described in the Appendix.

\section{A. Findings}

In this section we report the estimated model specified to explain cinema-revenue effects, and other models aimed at examining in more detail the timing hypothesis.

We draw four observations from the estimated revenue model reported in Table 1. First, parallel importing has a negative impact on New Zealand box office revenues at the 5\% level of significance. Second, the positive sign of the interaction dummy coefficient indicates that the effect of parallel importing on New Zealand cinemas' revenues is lower the later parallel imports arrive, though this effect is not statistically significant. This is consistent with our theory that arrivals of DVDs during a film's run in cinemas undermine box office revenues. Third, the elasticity of New Zealand box office revenues with respect to the US box office are significantly different from unity. We estimate a $1 \%$ increase in US box office revenue is associated with only a $0.78 \%$ increase in New Zealand box office revenue. This will reflect different film tastes of consumers in each country, and the fact that New Zealand consumers have more information about a film when it first appears in cinemas in that country. Fourth, after controlling for parallel importing, the delay in the cinematic release of a film is associated with a reduction in revenues as indicated by the negative sign of the cinematic release delay variable.

\footnotetext{
40 The continuous variables are in natural logarithms and we interpret the associated coefficients as elasticities.

41 There is potentially an endogeneity problem with this variable for which we do not have a good instrument. Distributors systematically release "blockbusters" sooner than other films, meaning short delay will be systematically related to high box office (not withstanding the control variable for US box office revenues).
} 
Table 1: Estimated Revenue Model. ${ }^{42}$

\begin{tabular}{ll}
\hline Independent Variables & $\begin{array}{l}\text { Coefficient } \\
\text { (standard error) }\end{array}$ \\
\hline Intercept & $\begin{array}{l}+10.9843^{* * *} \\
(0.3023) \\
\end{array}$ \\
US Box Office & $+0.7636^{* * *}$ \\
& $(0.0632)$ \\
Parallel Import Dummy & $-0.3409^{* *}$ \\
& $(0.1518)$ \\
Interactive Dummy & $+0.0015^{*}$ \\
& $(0.0009)$ \\
Cinematic Release Delay & $-0.0054^{* * *}$ \\
\hline $\mathrm{R}^{2}=0.6889 ;$ Adj $\mathrm{R}^{2}=0.6820 ; \mathrm{F}=98.5594 ;$ Obs $=183$. & $(0.0013)$ \\
$* * *$ significant at level of $1 \%$. & \\
$* *$ significant at level of $5 \%$. & \\
$*$ significant at level of $10 \%$. & \\
\hline
\end{tabular}

We now consider more formally whether parallel importing affects the timing of film releases, using the following simple model:

$$
E_{i}=\alpha+\beta D_{i}+\varepsilon
$$

where, as in the previous model, $E_{i}$ is the number of days between US and New Zealand release dates of film $i$ and $D_{i}$ is a dummy indicating whether the US release date of the film is in the period during which parallel imported DVDs were entering the country for rental. We use a period dummy to assess the the threat of parallel importing, as much as actual parallel on delay. We define the period of parallel importing to start at the date that the first parallel imported DVD arrived on 31 March 1999 according to data collected from records at a Wellington video rental store. The period is defined as ending on 30 November 2001 when the Video Ezy rental decision occurred. We estimate the equation using a data set of all films released in the US and New Zealand with US release dates between 1 January 1997 and 31 December 2002. We exclude films released in the US in 2003 because of the proximity to the end of 2003 at the time of this study is likely to bias the observed delay downwards (films released in 2003 with long delays will not yet have arrived in New Zealand).

We estimate the model on the full data set (792 observations) and a subset of films which earned over US\$10 million in US box office revenues (403 observations). ${ }^{43}$ The results are reported in Table 2.

\footnotetext{
42 The Lord of the Rings trilogy has been excluded from observations (see footnote 27). All standard errors estimated using White's 1980 covariance matrix that is robust against serial correlation and heteroscedasticity.

43 Data on films earnings revenues over US\$10 million from www.boxofficereport.com.
} 
Table 2: Effect of Parallel Importing on Delay ${ }^{44}$

\begin{tabular}{l|l|l}
\hline Independent Variables & $\begin{array}{l}\text { Full Data Set } \\
\text { Coefficient } \\
\text { (standard error) }\end{array}$ & $\begin{array}{l}\text { \$10M Min Revenue Subset } \\
\text { Coefficient } \\
\text { (standard error) }\end{array}$ \\
\hline Intercept & $\begin{array}{l}220.24 * * * \\
(17.1183)\end{array}$ & $\begin{array}{l}96.68 * * * \\
(5.64)\end{array}$ \\
Parallel Import Period Dummy & $-96.91 * * *$ \\
& $(20.23)$ & $\begin{array}{l}+5.45 \\
(7.95)\end{array}$ \\
\hline & $\begin{array}{l}\mathrm{R}^{2}=0.03 ; \text { Adj } \mathrm{R}^{2}=0.03 ; \\
\mathrm{F}=22.64 ; \text { Obs }=792\end{array}$ & $\begin{array}{l}\mathrm{R}^{2}=0.00 ; \text { Adj } \mathrm{R}^{2}=-0.00 ; \\
\mathrm{F}=0.46 ; \text { Obs }=403\end{array}$ \\
\hline
\end{tabular}

*** significant at level of $1 \%$.

Table 2 indicates that in the full data set parallel importing reduced the average delay between US and New Zealand cinema release dates by 96 days. However, the $R^{2}$ value indicates the proportion of the variation in delay being explained by the model is very low.

For the subset of the films which earned over US\$10 million revenue at the US box office, presented in the right hand column of Table 2, the equation is such a poor fit to the data it strongly suggests no relationship between parallel importing and shorter delay in the arrival of films in New Zealand cinemas relative to the US. The intercept term indicates high-earning films have shorter delays after controlling for parallel importing, as might be expected.

Taken together, these suggest that parallel importing systematically reduces the delay of lower-earnings films but not high-earnings films. This is consistent with the proposition that films of no more than moderate sales do not compete with the very high earnings films and hence modes of delivery - e.g. DVDs vs cinema - are more competitive for box-office hits. It also suggests that there is great value in waiting to find out whether a film is a box office hit in the country of first release before implementing a release strategy in New Zealand. It may be that box-office hits draw customers earlier in time as well as in numbers thereby rendering alternative modes of delivery that have any delay ineffective competition.

\section{CONCLUSION}

We have examined the effect of parallel importing on quality as measured by delay in the cinematic release of films and the availability of alternative media and presented evidence that parallel importing is associated with a significant improvement in quality as represented by timing. The delay in the cinematic release of films was significantly longer before and after a period in which parallel importing occurred, and most of this change was associated with relatively low-earning films. The parallel importing of a film

\footnotetext{
${ }^{44}$ Excluding films from Lord of the Rings. For an explanation see footnote 27.
} 
on DVD significantly reduced cinematic admissions but had a negligible effect on price.

Consumers value variety and the number of films released in NZ cinemas fell during the transition period after the ban on renting parallel imported DVDs was clarified in 2001, but this is consistent with the re-introduction of longer delays in local release and long run changes in the variety of films in cinemas cannot be inferred from the evidence. We found no evidence that parallel importing reduced the variety of films released in cinemas. Consumers value advertising expenditure because it lowers search costs. To the extent parallel importing undermines marginal revenues earned from advertising, consumers may be detrimentally affected by a reduction in the promotion of films by licensed distributors.

These results indicate that the overall effect of introducing parallel importing in the New Zealand film sector was to increase welfare. In particular, our assessment suggests consumers enjoyed benefits from parallel importing in the earlier release of films in all relevant media, that they substituted to other media (DVDs), and that, on evidence and argument, there would have been only limited costs. The distinction between rental and purchase of DVDs under legislation arbitrarily raised transactions costs for consumers materially limiting the benefits of parallel importation.

While the implications of this study for the assessment of vertical restraints within an economy cannot be translated directly to welfare considerations of national territorial restrictions, they do represent the sort of quantification that Rey and Stiglitz (1995) argue is missing in the evaluation of the efficiency of territorial restrictions. The study illustrates that delays in distribution may well have important welfare connotations in some industries; and it suggests that the DVD market constrains the cinematic market. Both of these may be useful in assessing the efficiency of vertical restraints in some particular markets. However, vertical restrictions may address particular retail problems rendering a general rule about their desirability problematic. ${ }^{45}$ Although the same may apply across nations, the transactions costs, even feasibility of, adjudication of individual international cases suggests that uniform parallel importation rules may be efficient.

The issue of parallel importing can only grow in importance as the means of rapid dissemination of information products grow and the ability of rights-holders to recoup investment across markets, rather than across time, improves in modern economies. Our results suggest considerable welfare gains may arise from not imposing rules that impede consumer access. This conclusion applies to economies that are sufficiently small that their actions do not affect investment in film making.

\section{REFERENCES}

Abbott, F. M. (1998), "First Report (Final) to the Committee on International Trade Law of the International Law Association on the Subject of Parallel Importation," Journal of International Economic Law 1:607-636.

Arfwedson, Jacob (2004), "Re-importation (Parallel Trade) in Pharmaceuticals," Institute for policy Innovation, Policy Report 182 (July). Available from www.ipi.org

Broda, Christian and David E. Weinstein (2004), "Globalization And The Gains From Variety,"

\footnotetext{
45 Whereas Posner (1981) suggests that vertical restraints should be per se legal, Rey and Stiglitz (1995:446) argue for a different approach.
} 
National Bureau Of Economic Research Working Paper 10314.

Carlton, Dennis W., and Jeffrey M. Perloff (2005), Modern Industrial Organisation, $4^{\text {th }}$ ed., Addison-Wesley, New York.

Chaudhry, Peggy E. (2004), "An Analysis of the Emergence of Gray Markets: A Generic Model," paper to AIB/JIBS Paper Development Workshop.

Chen, Yongmin (1999), "Oligopoly Price Discrimination and Resale Price Maintenance," RAND Journal of Economics 30, pp. 441-55.

Cosac, Teodora (2003), "Vertical Restraints and Parallel Imports with Differentiated Products," Canadian Competition Bureau Working Paper.

Dixit, A.K. and R.S. Pindyck (1994), Investment Under Uncertainty. Princeton University Press, Princeton, N.J.

Gans, Joshua S., Stephen P. King and Emily Dunt (2001), "The Economic Consequences of DVD Regional Restrictions,” University of Melbourne Working Paper (19 September).

Grenadier, S.R. (2002), "Option Exercise Games: An Application to the Equilibrium Investment Strategies of Firms," Review of Financial Studies 15, 691-721.

Hausman, Jerry (2003), "Sources of Bias and Solutions to Bias in the CPI", Journal of Economic Perspectives, 17(1), pp. 23-44.

Hilke, John C. (1988), "Free Trading or Free-Riding: An Examination of the Theories and Available Empirical Evidence on Grey Market Imports." World Competition. 32:75-91.

Krugman, Paul R. (1979) "Increasing Returns, Monopolistic Competition, and International Trade.” Journal of International Economics, November, 9(4), pp. 469-79.

Lambrecht, B.M. and W.R. Perraudin (2003), "Real Options and Preemption under Incomplete Information," Journal of Economic Dynamics and Control 27, 619-643.

Malueg, David A. and Marius Schwartz, "Parallel Imports, Demand Dispersion, and International Price Discrimination," Journal of International Economics 37 (1994):167-96.

Marvasti, Akbar, and Ray E. Canterbery, (2005), "Cultural Barriers and Other Barriers to Motion Pictures Trade", Economic Inquiry, 43(1), 39-54.

Maskus K.E. and Y. Chen (1999) "Vertical Price Control and Parallel Imports," Discussion Papers in Economics, University of Colorado at Boulder, Department of Economics.

Maskus K.E. and Y. Chen (2004), "Vertical Price Control and Parallel Imports: Theory and Evidence," Review of International Economics, Vol. 12, pp. 551-570, 2004.

Maskus, K.E. (2001), "Parallel Imports In Pharmaceuticals: Implications For Competition And Prices In Developing Countries," Final Report to World Intellectual Property Organization.

McCareins, Mark, R. and Brian E. Neufer, (1991), "Transhipping Under the Antitrust Laws", DePaul Business Law Journal, 3(2), spring/summer, 285-304.

National Economic Research Associates (1999), The Economic Consequences of the Choice of Regime in the Area of Trademarks, London.

Novy-Marx, R. (2004), “An Equilibrium Model of Investment Under Uncertainty,” University 
of Chicago Graduate School of Business mimeo.

Posner, R., (1977), "The Rule of Reason and the Economic Approach: reflections on the Sylvania Decision," University of Chicago Law Review, 45, 1-20.

Posner, R., (1981), "The Next Step in the Antitrust Treatment of Restricted Distribution: Per Se Legality", University of Chicago Law Review, 48(6), 6-26.

Rey P., and J. Stiglitz, (1995),"The Role of Exclusive Territories in Producers Competition," The Rand Journal of Economics, 26(3), 431-452.

Rothnie, Warwick A. (1993), Parallel Imports. London: Sweet and Maxwell.

Valletti, Tommaso M. and Stefan Szymanski (2004), "Parallel Trade, International Exhaustion and Intellectual Property Rights: A Welfare Analysis," Working Paper, 30 July.

Warner, John T. and Saul Pleeter (2001), "The Personal Discount Rate: Evidence from Military Downsizing Programs," American Economic Review, 91:1, pp. 33-53.

White, H., 1980, “A Heroskedasticity-Consistent Covariance Matrix Estimator and a Direct Test for Heteroskedasticity", Econometrica, 48, 817-838.

Wolf, Martin (2004), Why Globalization Works, Yale University Press.

\section{APPENDIX: DATA SOURCES}

US box office receipts are taken from www.boxofficereport.com. This database includes films that earn more than US\$10 million in US cinemas. New Zealand box office revenues are from the New Zealand Motion Picture Distributors Association. Both New Zealand and US box office revenues are deflated by nominal disposable income in New Zealand and the US, and we take the natural logarithm of both. Our hypothesis is that box office revenue growth is a positive function of disposable income. We deflate films box office revenue by the annual deflator for year in which the film is released in each country.

Parallel import data is obtained from a video store in Wellington New Zealand, United Video Courtenay Place, which has computer records of all DVDs imported since 1997 including the date of their arrival. All Region 1 DVDs are assumed to be parallel imports since, to our knowledge no mainstream films DVDs were released locally by licensed distributors on the Region 1 format.

We have 185 observations for films first released between 1997 and 2003, of which 59 were parallel imported. The first parallel import is recorded as arriving 31 March 1999 and the last on 2 November 2001.

The data for the subsidiary (timing equation relating to E) consist of the set of all films released in the US and New Zealand with US release dates between 1 January 1997 and 31 December 2002 as recorded by www.imdb.com. 